\title{
Inclusive entrepreneurship: A critical look at inclusion of persons with disabilities
}

\author{
JoAnn Rolle \\ Jacqueline Kisato \\ Kenyatta University, Kenya \\ Patricia Rock \\ BlueSuite Solutions, Inc., USA \\ Jacqueline Winstanley \\ Universal Inclusion, United Kingdom
}

Dean, Business School, Medgar Evers College, City University of New York, USA

Keywords

Inclusive entrepreneurship, inclusivity, persons with disability.

\begin{abstract}
There have been many definitions of inclusion as it relates to the underserved and economic empowerment through entrepreneurship, but few of these definitions have focused specifically on persons with disabilities.

Purpose of Research-Many studies have looked at increasing economic empowerment through entrepreneurship for women, minorities, youth, seniors, immigrants, and rural residents throughout literature. The gap however is that the lumping of all these categories has led to the overlooking of specific challenges faced by persons with disabilities. This oversight on economic inclusivity has been magnified especially during the Corona virus pandemic.

Design/Methodology- This study reviews literature in search of evidence to document programs, projects, and policies used in both developed and developing countries to address the challenges of inclusive entrepreneurship for all. The paper explores several entrepreneurial studies on inclusivity of business ecosystems in UK, USA, Sub Saharan Africa, and India and highlights public-private partnerships and impact investment as it relates to challenges in increasing inclusivity in businesses.

Results/Findings- It was evident that, while there are many government policies and programs to support entrepreneurship in the USA,UK, Sub Saharan Africa and India, limited empirical studies have been documented to evaluate the impact of these policies on entrepreneurship for persons with disabilities. Some of the challenges cited in literature included gender gap, cost of doing business and the likelihood to be funded to launch a business, as common dominant factors reported on the issue of inclusion.

Practical implications and Conclusions-The authors find that there is much more empirical research and analyses warranted in the study of entrepreneurship inclusion and empowerment of the underserved especially for persons with disabilities and continue reviewing literature and use quantitative and qualitative research such that additional programs, projects and policies may be developed to serve all inclusively.
\end{abstract}

\subsection{Introduction: Defining Inclusive Entrepreneurship}

Inclusivity, from a macro perspective, is a term used to refer to a societal way of living that is accessible to everyone and has benefits for all in daily life (INCLUDE, 2019, Pilkováa A, *, Jančovičováa Z,\& Kovačičováa $Z$, 2016). Both inclusiveness and inclusivity are developed to counter exclusion thus, ensuring that no one is left behind in developmental matters. Rauniyar, G., and Kanbur, R. (2009) define inclusive development with regard to changes that improve social and economic conditions across the population in a given country. To further explain inclusivity, INCLUDE (2019) used the Inequality-adjusted Human Development Index (IHDI) report to show that there is a loss of $33 \%$ in human development values due to inequality and lack of inclusiveness in development. 
Inclusive entrepreneurship as a concept refers to the participation of persons from marginalized groups in entrepreneurship for economic and social development (Pilkováa A. et al., 2016). In an inclusive society, the marginalized groups are catered for through policy and initiatives that ensure all persons are included in development matters. Conversely, the lack of inclusiveness, especially in economic development in a society, leads to marginalized persons being left out and relegated to poverty and other negative outcomes (Rauniyar \& Kanbur ,2010: UNCTAD,2019).

Various scholars have studied inclusivity in entrepreneurship globally in relation to United Nations Sustainable Development Goals (UNCTAD, 2019: Thompson H., Shepherd, B., Welch, G. \& Anyimadu, Adjon ,2017, Rolle J.D \& Kisato J., 2019). In most of these studies, the authors have limited their study to inclusivity of entrepreneurial activity for youth, women and seniors, without addressing persons with disabilities in particular (Pilkováa A. et al., 2016). There have been research on public-private partnerships and impact investment programs to enhance inclusivity in entrepreneurship in many countries. For instance, in Sub Saharan Africa and India, studies have focused on the age gender gap in relation to inclusivity without addressing policies related to persons with disabilities (Ganesh,U; Memon, V.; Kaushl,A.; Kumar, K.,2018: Rolle J.D \& Kisato J., 2019; OCED, 2019; Ntonta, J.;2019).The specific focus on persons with disabilities generally, has been lacking, perhaps due to their numbers or the lack of critical analysis on the needs of these groups.

INCLUDE (2019) on the other hand, reiterates that there are improvements in developmental programs and policies in many countries globally, but the distribution of improved wellbeing has been uneven, further highlighting the oversight about persons with disabilities in marginalized groups. OECD (2019) further posits that economic growth does not directly translate to poverty reduction if the trickledown effect to the marginalized in society is not as successful. If the most vulnerable groups of persons are excluded or overlooked, inclusive economic growth becomes sufficiently invisible in global and national economic statistics and exacerbates poverty in the most vulnerable groups (UNCTAD, 2019).

Literature shows that the concept inclusivity is viewed differently in different sectors and academic disciplines (OCED, 2019: UNCTAD, 2019). The lack of a well-accepted definition of inclusivity in entrepreneurship with regard to persons with disabilities, may pose a challenge in identifying clear inclusivity of these groups' entrepreneurial ventures. While we acknowledge that there have been efforts to make entrepreneurship more inclusive in economic development indices, a critical look at this group is imperative. Evidently, the needs of entrepreneurs are not homogeneous, and a more critical look is required in empirical studies to understand these disparities especially for persons with disabilities.

Many of the studies done in the area of inclusivity, have lumped up women and girls, ethnic minorities, indigenous people, persons with disabilities and migrants, but not paid special attention to policies related to persons with disabilities ((Pilkováa A. et al., 2016; INCLUDE, 2019; Rolle J.D \& Kisato J., 2019). Such perspectives ignore unique variables that are critical for such groups to succeed in entrepreneurial venture. This paper reviews literature on studies of inclusive entrepreneurship that scholars have pursued in an effort to show inclusivity in entrepreneurship.

\subsection{Literature Review}

\subsection{Inclusiveness in the Sustainable Development Goals (SDGs)}

In 2015, global leaders as members of the United Nations convened to establish sustainable development goals to be achieved by 2030. Replacing the 2000 Millennium Development Goals (MDGs) meant to address global poverty, the SDGs address the nuanced social challenges that undermine growth and progress throughout the world including economic injustice, gender inequality and ability and accessibility barriers (United Nations Development Programme, 2020). With the intention to tackle the "triple bottom line" approach to overall human wellbeing; economic development, environmental sustain ability, and social inclusion, SDGs offer a framework for countries to adopt to see these efforts through (Vandemoortele, J. (2017).

Specifically, SDG 8 states its intention to "promote sustained, inclusive and sustainable economic growth, full and productive employment and decent work for all." (United Nations, 2015). Further, goal 8.3 recommends "development-oriented policies" that promote and foster job creation, entrepreneurship and innovation with the intent to formalize systems that support business of all sizes, especially through the access of financial services (United Nations, 2015). These specific goals provide a springboard from which 
many countries can establish programming and policies that address the needs of traditionally underserved populations. The overarching concept of inclusive entrepreneurship can be defined as one that represents an involvement of under-represented groups into entrepreneurship with the aim to help them overcome their economic and social problems (Pilkováa, et al., 2016; Vandemoortele, J., 2017).

Simultaneously, various governmental agencies and non-governmental organizations (NGOs) in countries, some of whom subscribed to the SDGs, have launched initiatives that embrace inclusive entrepreneurship for underserved classes. These efforts appear to parallel the progress and intention for the SDGs themselves. The 2017 United Nations Conference on Trade and Development (UNCTAD) report Innovation, diversification and inclusive development in Africa points out that there was negligible progress in SDG attainment of inclusive development, (UNCTAD, 2019). In South Africa, for instance, scholars have reported that inequality and lack of inclusivity has had long term implications for growth and poverty reduction among the blacks (OECD 2012). Additionally, innovation for the marginalized groups globally, has been slow and limited in most African countries, further exacerbating the inclusiveness in entrepreneurship and economic well-being of marginalized groups.

\subsection{Examples of Global Inclusive Entrepreneurship Programs}

The United Nation Development Programme (UNDP) suggests that both markets and ecosystems need to be reviewed to address the challenge of developing enterprises by the underserved. In the report, "Realizing Africa's Wealth, Building Inclusive Businesses for Shared Prosperity," UNDP defines four focus points. The defined areas to develop inclusive businesses information, incentives, investments, and implementation support (UNDP 2013). The report categorizes businesses as mainstream vs. inclusive and refers to markets served, and business models used (UNDP 2013).

When referencing inclusiveness, UNDP suggests that both markets and ecosystems be reviewed to address the challenge of developing enterprises by the underserved. In the report, "Realizing Africa's Wealth, Building Inclusive Businesses for Shared Prosperity," UNDP defines four focus points. The defined areas to develop inclusive businesses information, incentives, investments, and implementation support. (UNDP 2013) The report categorizes businesses as mainstream vs. inclusive and refers to markets served, and business models used (UNDP 2013). The study presented many case studies including many enterprises in several African countries addressing selected industry sectors.

In a recent study of business development in Sub-Sahara Africa several common factors were found to impede growth: limited access to finance; poor infrastructure; a constrained pool of skill workers; and corruption. (Thompson H. et al., 2017). Specifically, within Tanzania job creation within urban areas where it is more densely populated continues to be a challenge, as well as opportunities for women.

"Young people living in urban areas are more likely to be unemployed than are those living in rural areas, and young women are half as likely as young men to be in regular employment. The situation is markedly worse in Zanzibar: youth unemployment is over 30 per cent, and young people make up the majority of those who are underemployed or economically inactive" (H. Thompson, 2017).

Technology was cited to leverage growth potential of the underserved, however it was also cited that education and skills of the workforce constrained prospects for developing and scaling businesses (Thompson H. et al., 2017; Rolle J.D \& Kisato J., 2019). In the recent United Nations Conference Trade \& Development (UNCTAD) Report, "Borderline: Women in Informal Cross- Borderline Trade, Malawi, the United Republic of Tanzania, and Zambia," Tanzania, as compared to others in the region has more complexity, costs, time to start a business and is ranked as one of the most difficult to start a business (UNCTAD, 2019). The issue of inclusion of persons with disabilities in entrepreneurial venture is not emphasized since the "women factor" is a more urgent challenge for these countries.

\subsection{Inclusive Entrepreneurship Policies and Programs in Sub Saharan Africa}

In most African countries, the role of entrepreneurship cannot be understated (Rolle J.D \& Kisato J., 2019; Thompson H. et al., 2017; UNCTAD 2019). These enterprises have been categorized as micro, small and medium (MSME) enterprises and account for 92 percent of all businesses in Ghana, 91\% in South Africa and provide $85 \%$ of employment in Kenya. While the focus has been on entrepreneurship in general, there has been little focus in research on inclusive entrepreneurship for persons with protective characteristics in these countries. 
To further understand how inclusive development has been under studied, an analysis carried out by INCLUDE (2019) revealed that policy makers in Kenya's vision 2030 seemed to have overlooked inclusive development and growth within its framework thus making inequality in income dimension especially for persons with protective characteristics, less prominent (Republic of Kenya, 2006). Similarly, Uganda's second national development plan 2015/16-2019/20, proposes becoming a middle-income country by 2020 through 'Strengthening Uganda's competitiveness for sustainable wealth creation, employment and inclusive growth' with no reference to persons with protective characteristics (Republic of Uganda, 2015).

In West Africa, and Ghana in particular, National shared growth and development agenda 2, 20142017 does not mention inclusive development nor inclusive growth despite using 'shared growth' to signify a focus on equality (Republic of Ghana, 2014). Nigeria's Vision 20:2020 mentions the aspect of 'sustainable growth', in reference to "optimizing human and natural resources to achieve rapid economic growth, and translating that growth into equitable social development for all citizens" (Federal Republic of Nigeria, 2009) with little reference to persons with protective characteristics.

It is evident therefore that a number of inclusive development policies have failed to mention persons with protective characteristics, thus posing a challenge in establishing if any specific programs have been instituted to cater for this group (INCLUDE, 2019). It is recommended that further research on this topic is imperative while looking at recent developments in mid-term or sector-specific policy papers in each of the said countries.

\subsection{Inclusive Entrepreneurship Policies and Programs in India and Europe}

Further ashore in Asia, January 2020 report of Global Economic Monitor (GEM) indicates that in India the economic gender gap is cited as a factor in inclusiveness, only $25 \%$ of women compared to $82 \%$ of men engage in the labour market. Of those women that do participate, one-fifth receive the income that males earn (Ph.D. Research Bureau, 2020). Even in this report, the main focus of the underserved is the youth and women with little reference to persons with protective characteristics, whose challenges might be overlooked in the long run. Further, it was reported that there was negligible progress towards inclusive development as far as innovation and diversification specifically, resulting in the disappointing progress in attaining the SDG (UNCTAD, 2017).

In Europe, inclusive entrepreneurship objectives are diverse and have several policy portfolios. There are inclusive entrepreneurship objectives for Youth; Women; Seniors; People with disabilities; the unemployed and immigrants (OECD, 2018, United Nations, 2015). As summarized in figure 1, inclusive entrepreneurship objectives have been instituted across various policies, but the number of countries that have implemented these policies in their portfolios are still low. For example, only 15 countries' entrepreneurs are from one or more underrepresented groups in entrepreneurship or business development strategies as shown.

Figure 1: Inclusive entrepreneurship objectives span across various policy portfolios

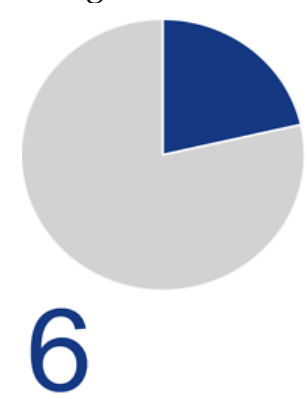

countries have a dedicated youth entrepreneurship strategy or women's entrepreneurship strategy.

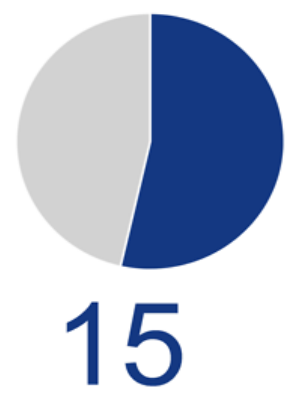

countries include entrepreneurs from one or more underrepresented or disadvantaged groups in an entrepreneurship or business development strategy.

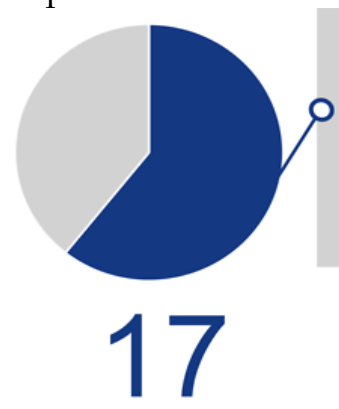

countries include references to entrepreneurs from one or more under-represented or disadvantaged groups in an employment strategy, a gender equality strategy or another social inclusion strategy.

Note: Estimates only national level strategies.

Source: Estimates based on OECD (2018) country notes on inclusive entrepreneurship policy. 
As the data in the chart reflects, few countries have dedicated youth, women's, and persons with disabilities entrepreneurship strategies, which are where the highest levels of need are. Therefore, the authors find there is much more research and analyses warranted in the study of inclusion and empowerment of the underserved including persons with disabilities. It is our goal to continue our review of the literature to identify additional quantitative and qualitative research such that new programs, projects, and policies may be developed to serve all inclusively.

Several programs have emerged in the UK in response to limited support in entrepreneurship for persons with disabilities, one such program is Universal Inclusion. Universal Inclusion launched in 2013 as a self-employment / entrepreneurial alternative to life on benefits and intergenerational poverty. The organization's programs facilitate innovation and entrepreneurship skill/mind sets yielding contributions and economic growth by persons with disabilities. Recently Universal Inclusion's programming led to the creation of an all-party parliamentary group within Westminster specifically for Inclusive entrepreneurship.

\subsection{Public-Private Partnerships and Impact Investment to enhance Inclusive Entrepreneurship}

In line with SDG goal 8, various governmental agencies and non-governmental organizations (NGOs) in different countries, some of whom subscribed to the SDGs, have launched initiatives that embrace inclusive entrepreneurship for underserved classes. These efforts appear to parallel the progress and intention for the SDGs themselves. At this time, limited research and policy recommendations exist regarding the application, practicality, and fidelity of the SDGs specifically. Yet, a growing body of research does support the efforts made by individual governments and NGOs that align fundamentally with the SDG planners.

One significant stride toward the SDGs currently exists in The Democratic Republic of the Congo where the Kadiwaku Family Foundation is implementing an aptly named Inclusive Entrepreneurship for people with disabilities program, serving an inclusive workforce of over 2,500 persons with disabilities and other underserved and marginalized designations to participate in the market either as employees or entrepreneurs (Ntonta, 2019). As a direct response to goal 8 which intends to support inclusive entrepreneurship, job creation and decent work for underserved populations, this programming is one that has developed in response to the SDG criterion.

In the USA, a three-year Onondaga County led initiative funded by the United States Labour Office of Disability Employment Policy managed by the Syracuse University Burton Blatt Institute with partners from the Whitman School of Management and others culminated in the launch of Start-up NY, a program focused on the inclusion and support of entrepreneurs with disabilities as well. Utilizing a 4-stage entrepreneurship curriculum, the program's entrepreneurial awareness, market research, business planning and sustainability, utilizing community-based stakeholders, existing governmental funding resources and state-wide partnerships was used as a model of inclusive entrepreneurship.

\subsection{Research Methodology}

This paper reviewed literature on different inclusive entrepreneurship studies across Sub-Saharan Africa, India, Europe, and USA. The main focus was on identifying inclusive entrepreneurship initiatives and programs that had an emphasis on persons with disability/protective characteristics. The study also examined the extent to which SDGs, policies and programs in entrepreneurship have incorporated inclusivity in their initiatives in the selected regions. The authors finally highlighted the existing gaps and proposed areas for further research that would enrich the concept of inclusivity in entrepreneurship, especially for the underserved.

\subsection{Findings}

Inclusive entrepreneurship work happening parallel to the SDG standards currently exists in the Ukraine, throughout the European Union, within the Visegrad4 (Czech Republic, Hungary, Poland, and Slovakia) and in the United States. In the Ukraine, ensuring the wellbeing of people with disabilities has particularly been a top priority and in turn, policies, education, infrastructure, ethics, investment, employment and social protections have all been part policy development of major economic policy development and have fostered inclusive entrepreneurship efforts (Skrylnik A., Valiavskiy, S.; Voloshina, O., 2019). 
Specifically, through the examination of micro, macro and regional variables barring persons with disabilities from economic success, Ukraine has established policies and practices to support inclusive initiatives. These practices and support for inclusive entrepreneurship models, employment models that promote inclusion and integration, subsidizing small business models that create the conditions to support the needs of persons with disabilities, allowing service provision offered by persons with disabilities that is also competitive in the greater market, the establishment of public institutions as inclusive spaces and finally, appropriate, relevant and competitive training for the support of those with disabilities" (Skrylnik A et al, 2019; Pilkováa A. et al., 2016).

\subsection{Discussions and Conclusion}

The recent Corona virus pandemic has brought to fore the major challenges on inclusivity in development. The more highlighted areas have been the working poor, the small businesses, and marginalized persons. Although the lack of clarity in the term inclusive entrepreneurship has its merits, by creating the fuzziness of the concept metaphoric power that allows for a multi-disciplinary and multi sectorial approach, it carries the danger that the term is co-opted and used as a smoke screen to exclude others in the entrepreneurial process. For example, policy makers claim that they promote inclusivity in entrepreneurship by focusing on strategies that promote economic growth without addressing inequality especially for persons with disabilities/protective characteristics.

At this time, limited research and policy recommendations exist regarding the application, practicality, and fidelity of the SDGs specifically. Yet, a growing body of research does support the efforts made by individual governments and NGOs that align fundamentally with the SDG planners. We will continue to explore examples of inclusive entrepreneurship efforts internationally and examine implementation standards carried forward by countries utilizing the SDG lens as well as those who established their inclusive entrepreneurship effort independent of the SDG standards.

\subsection{Limitations and Directions for Research}

Whereas definitions assist in the understanding and conceptualizing of inclusive entrepreneurship, the paucity of empirical research that pays special attention to inclusive entrepreneurship for persons with disabilities is a major drawback. From our analysis, there are limited empirical studies available to exclusively support the fidelity of SDGs thus far. We note, however, that in several countries there have been good faith efforts towards fostering a more inclusive workforce and empowering underserved and overlooked communities including women, persons with disabilities, youth, and seniors. It appears that these programs have developed parallel to the efforts of the SDG crafters to encourage inclusive entrepreneurship, nonetheless, but clear metrics of empirical research is required to assess inclusivity outcomes.

While inclusive entrepreneurship as a concept is publicly accepted as a viable career choice, there is still a need for comprehensive policy and infrastructure development to sustain these inclusivity goals. The concept of inclusive entrepreneurship is vast in breadth and scope, thus resulting in varying definitions and implementation practices the world over. Concretizing clear guidelines and operational definitions for inclusivity will foster better programming and policy development that can be generalized and adopted throughout.

\section{References}

African Economic Outlook (AEO), (2017) Statistics, Real GDP growth rate. Retrieved from: http://www.africaneconomicoutlook.org/en/statistics 2019) Inclusive Development in Africa:

Ganesh, U; Memon, V.; Kaushl, A. and Kumar, K., (2018) The Indian Social Enterprise Landscape Innovation for an Inclusive Future,

https://www.bertelsmann-

stiftung.de/fileadmin/files/Projekte/7_Deutschland_und_Asien/Study_The_Indian_Social_Enterprise_Lands cape_2018.pdf\#page=79

Global Economic Monitor: Ph.d. Research Bureau (2020),

https://www.phdcci.in/wp-content/uploads/2020/01/Global-Economic-Monitor-January-2020.pdf

INCLUDE (2019). Synthesis Report: Inclusive Development in Africa, March 2019. Retrieved from https://includeplatform.net/wp-content/uploads/2019/07/ID-synthesis-INCLUDE-Final.pdf 
Ntonta, J. (2019) Inclusive entrepreneurship for people with disabilities in DR Congo. Retrieved from https://www.entrepreneurship-campus.org/ideas/24/13262/.

OECD/European Union (2015). The Missing Entrepreneurs 2015: Policies for Self-employment and Entrepreneurship, OECD Publishing, Paris. Retrieved from:

https://www.oecd-ilibrary.org/sites/74f22f51- en/index.html?itemId=/content/component/74f22f51-en

Pilková, A. Jančovičová, Z. and Kovačičová, Z. (2016). Inclusive entrepreneurship in Visegrad4 countries. Procedia Social and Behavioral Sciences 220. $312-320$.

Rauniyar, G., and Kanbur, R. (2009). Conceptualizing inclusive development: with applications to rural infrastructure and development assistance. Asian Development Bank.

Republic of Ghana. (2014). National shared growth and development agenda 2, 2014-2017. Retrieved from: http://www.un-page.org/files/public/gsgda.pdf

Republic of Kenya. (2006). Kenya vision 2030. Retrieved from: http://vision2030.go.ke/

Republic of Uganda. (2015). Second national development plan 2015/16-2019/20. Retrieved from: http://npa.ug/wpcontent/uploads/NDPII-Final.pdf

Rolle J.D \& Kisato J. (2019) The future of work and entrepreneurship for the underserved. Conference proceedings of the Academy of Business and Retail Management (ABRM), USA. The Business and Management Review, Volume 10 Number 2.

Shaheen, G. (2016). Inclusive Entrepreneurship: A Process for Improving Self-Employment for People with Disabilities, Journal of Policy Practice. 15:1-2, 58-81

Skrylnik, A.; Valiavskiy, S.; Voloshina, O. (2019) Inclusive entrepreneurship infrastructure development: Special Aspects in Ukraine. International Journal of Engineering \& Technology (7).

Thompson, H.; Shepherd, B.; Welch, G.and Anyimadu, Adjon (2017) Developing Businesses of Scale in Sub-Saharan Africa Insights from Nigeria, Tanzania, Uganda, and Zambia. Retrieved from:

https://www.chathamhouse.org/sites/default/files/publications/research/2017-09-08-business-of-scale-africathompson-shepherd-welch-anyimadu-final.pdf

United Nations (2015) Sustainable Development Goals. Retrieved on February 29, 2020 from:

https://sustainabledevelopment.un.org/

United Nations (2015) Sustainability Goals, SDG8. Retrieved on February 29, 2020 from

https://sustainabledevelopment.un.org/sdg8

United Nations Conference on Trade and Development. (2017). Innovation, diversification, and inclusive development in Africa. UNCTAD research paper No. 2, 2017. Retrieved from:

http://unctad.org/en/PublicationsLibrary/ser-rp-2017d2_en.pdf

UNCTAD (2019) Borderline: Women in Informal Cross- Borderline Trade, Malawi, the United Republic of Tanzania, and Zambia. Retrieved from:

https://unctad.org/en/PublicationsLibrary/ditc2018d3_en.pdf\#page=57

UNDP (2013) Realizing Africa's Wealth, Building Inclusive Businesses for Shared Prosperity https://www.undp.org/content/dam/undp/library/corporate/Partnerships/Private\%20Sector/IBE/UNDP \%20AFIM\%20Realizing\%20Africas\%20Wealth.pdf\#page $=53$

Vandemoortele, J. (2017). From MDGs to SDGs: critical reflections on global targets and their measurement. Chapter 3 in: Van Bergeijk, P.A.G. and Van der Hoeven, R. (2017). Sustainable Development Goals and Income Inequality. Edward Elgar Publishing. 